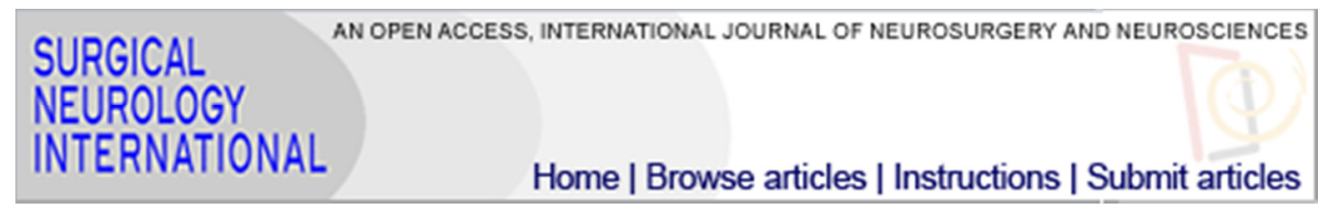

Surg Neurol Int. 2012; 3: 10

Published online 2012 January 21. doi: $\underline{10.4103 / 2152-7806.92180}$

PMCID: PMC3280002

\title{
Dermoid tumor of the lateral wall of the cavernous sinus
}

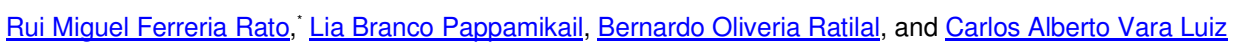

Department of Neurosurgery, Centro Hospitalar de Lisboa Central EPE, Lisboa, Portugal Rui Miguel Ferreria Rato: ruimfrato@gmail.com ; Lia Branco Pappamikail: pappamikail@gmail.com ; Bernardo Oliveria Ratilal: bratilal@yahoo.com ; Carlos Alberto Vara Luiz: cvaraluiz@netcabo.pt

"Corresponding author

Received October 10, 2011; Accepted December 27, 2011.

Copyright : (c) 2012 Rato RMF.

This is an open-access article distributed under the terms of the Creative Commons Attribution License, which permits unrestricted use, distribution, and reproduction in any medium, provided the original author and source are credited. Go to:

\section{Abstract}

Background:

Congenital intracranial dermoid tumors are very rare. The location of these dermoid lesions in the cavernous sinus and the complexity of the operative procedure for these lesions have been noted by several authors. Dermoid tumors originating in the cavernous sinus are usually interdural, and thus blurred vision is an uncommon presentation.

\section{Case Description:}

Herein we report the first incidental case of a cavernous sinus dermoid cyst in a 21-year-old woman.

\section{Conclusions:}

A literature review was done and the possible treatments and approaches for this lesion are discussed. We consider that surgical treatment is indicated in most incidental cavernous sinus dermoid lesions due to the possible symptoms related to compression or rupture leading to chemical meningitis.

Keywords: Cavernous sinus, dermoid cyst, interdural Go to:

\section{INTRODUCTION}

Dermoid cysts are rare tumors, constituting less than $1 \%$ of intracranial tumors. They are benign congenital tumors originating from ectopic inclusion of epithelial cells during closure of the neural tube in the third to fifth week of embryonic development.[2,9,23] These cystic lesions comprise skin elements such as keratin, hair, sebum, a thick semiliquid fatty substance, and epithelial debris. They expand slowly by progressive desquamation of capsular components into the interior of the cyst and typically become symptomatic during childhood.[18]

Intracranial dermoids are most commonly seen below the tentorium.[23] Dermoid cysts confined to the cavernous sinus have seldom been reported in the literature.[1, $\underline{8}, 17]$ Epilepsy is the most common presentation of supratentorial dermoid cysts.[17] Other symptoms are related to compression of adjacent neural structures resulting in focal neurological dysfunction or obstruction of cerebrospinal pathways.[9,17] Dermoids may also become symptomatic due to rupture which results in spillage of contents into the subarachnoid space and the ventricles,[] resulting in an aseptic chemical meningitis, vasospasm, infarction, or increased intracranial pressure.[9,17] Intraventricular fat can occlude ventricular foramina, causing increased intracranial pressure, which may be motion dependent due to the lower specific weight of lipids compared to cerebrospinal fluid (CSF).[15] Arachnoiditis or chronic ventriculitis due to the repeated leakage of cystic contents into the subarachnoid or ventricular system may produce hydrocephalus or cognitive deterioration.[15] 
A 21-year-old woman was seen in the outpatient clinic, with a long-lasting daily mild headache, tension-type, localized to the right hemisphere, constant, with no spontaneous relief.[13] Neurological examination was normal.

Computed tomography (CT) scan revealed a hypodense left parasellar region lesion and Magnetic Resonance Imaging (MRI) revealed a T1 and T2 hyperintense lesion [Figures [Figures1 1 and and22].

A conservative treatment was decided upon, and the headache was successfully treated with nonsteroidal anti-inflammatory drugs. At 6 months, the patient had an $80 \%$ Snellen Chart eye exam decreased on left eye visual acuity. No other neurological abnormalities were found. We decided for a left frontotemporal craniotomy to perform an intradural approach of the cavernous sinus. The external dural layer of the cavernous sinus was opened. The lesion originated from the cavernous sinus and attained a large size by splitting and displacing the temporal dural layer and true cavernous membrane (inner layer). Intense milky and greasy fluid was aspirated before numerous hair tufts were removed from the inner side of the firm, capsulated lesion [Figure 3]. Cranial nerves became visible through the inner layer of the cavernous sinus after gross total tumor debulking.

Histopathologic examination of the specimen confirmed a dermoid cyst [Figure 4].

The postoperative period was uneventful [Figures [Figures55 and and6].6]. Figure 7 shows 2-month post-op MRI. At 6-month follow-up, there was a visual acuity improvement although no change for the better was noticed for headache.

Go to:

\section{DISCUSSION}

Dermoid cysts, which are thought to originate from ectodermic remnants, tend to be located close to midline structures and are generally seen in the early decades of life.[4] They are about 3-10 times less frequent than epidermoid tumors and they constitute $0.04-0.7 \%$ of intracranial tumors.[12] Dermoid cysts bear a capsule composed of stratified squamous epithelium and they contain dermal elements such as hair and sebaceous glands. Unlike teratomas, which have tissue representative of all three germinal layers, dermoids have tissue representative of only the ectoderm.[17] The cyst material can vary in consistency depending upon the ratio of the various elements within the wall.[9, 15$]$ Given that dermoid cysts increase slowly in volume over time, they tend to grow in intracranial subarachnoid spaces that offer minimal resistance, such as cisterns, sulci, or fissures.[25]

Enlargement of these cysts occurs by secretion of dermal elements. The mean duration of symptoms before presentation of supratentorial dermoid cysts varies from 3 months to 6.9 years.[17]

Dermoid tumors of the cavernous region present unique clinical signs, particularly oculomotor nerve palsy. Characteristics occur quite late in the clinical course due to the slow growth pattern of these lesions. Clinical features such as headaches, hemiparesis, visual field defects, signs of increased intracranial pressure, seizures and, less likely, meningeal signs, exophthalmos, and oculomotor palsy have all been reported for dermoid cysts.[17,21,25] Diplopia and decrease in visual acuity were rarely encountered.[21]

Supratentorial dermoid cysts are usually located in the suprasellar, parasellar, temporal, and frontobasal regions.[4] Dermoid cysts of the cavernous sinus are rare and the few reported cases are described as intracranial rather than extradural or interdurally localized dermoid cysts originating from the cavernous sinus. $[1, \underline{8}, 10,17,19,25]$ The lateral dural wall of the cavernous sinus is composed of two layers: the outer dural layer (dura propria) and the inner membranous layer. Although intracranial dermoids have usually been reported as extradural, intradural, or parasellar lesions,[3] and adhered to great venous structures such as the cavernous sinus,[17] purely interdural dermoid cysts of the cavernous sinus were first defined by Nakagawa et al.[19]

The inner membranous layer separates these tumors from the venous channels of the cavernous sinus. Tumors of the lateral wall include trigeminal neurinoma of the ophthalmic nerve and oculomotor and trochlear neurinomas. Other tumors that may be confined to the lateral wall are epidermoid cysts, metastatic tumors, melanomas, and cavernous angiomas.

The decision was on whether a surgical treatment should be immediately taken. Although we preferred for a conservative treatment until visual acuity deterioration was noted, from the literature review we found no previous incidental cavernous dermoid cysts reported [Table 1]. Even if this pathology is extremely rare, our patient developed tumor-related symptoms in a short period of time after the diagnosis, which were not clearly associated with a radiological tumor growth. We think an increase of the intra-tumoral pressure may have been the cause of the symptoms' onset.

Lunardi et al. reported three cavernous dermoid cysts, one of which, as in our case, had no clinical signs of ophthalmoplegia. They pointed out the attachment of these lesions to the cavernous sinus, but did not explain whether these lesions have an exact cavernous infiltration.[8] Our case is the first simultaneously described with no signs of ophthalmoplegia, a well-described interdural localization, as well as a point of attachment to the inner membranous layer of the lateral wall of the cavernous sinus.

The imaging characteristics of dermoid cysts depend on the contents of the lesion. CT scans show these lesions to be homogenous with attenuation compared to that of CSF. Hair and the sebaceous contents of the cyst give the dermoid a heterogeneous appearance on MRI and the fat content is seen as hyperintensity on T1-weighted MRI and hypointense to mixed signals on T2-weighted MRI.[16] The fat content of a dermoid cyst varies widely and the presence of fat in a cystic lesion is considered diagnostic of a dermoid cyst. MRI permits the recognition of interdural cavernous sinus dermoid tumors from their typical smooth contours, oval shape, and medial displacement of the intracavernous portion of the internal carotid artery without effacement or narrowing. In contrast, intracavernous and invasive tumors tend to encase and narrow the internal carotid artery.[14] In our case, an interdural localized dermoid tumor was suspected and a surgical approach was planned accordingly. 
In the previous cases, approaches to the cavernous sinus, such as pterional (fronto-temporal), orbito-zygomatic, and subtemporal, have been described [Table 1]. Fronto-orbito-zygomatic craniotomy was the preferred approach, which provides a wide exposure of the temporal lobe and facilitates tumor removal. We decided for the fronto-temporal approach in the present case. After opening the anterior half of the Sylvian fissure, we could easily access the anterior segment, the cavernous sinus, in which the tumor was located, with minimal brain retraction. Subtemporal approach would require temporal brain retraction with higher morbidity, and we felt that in our patient, pterional approach would be enough and an orbito-zygomatic extension would add real value for tumor removal.

Yasargil et al., in their landmark series of 43 operated patients with dermoids and epidermoids, reported meningitis and transient cranial nerve palsies as the most common postoperative complications.[25] Yasargil et al. state the removal of the capsule itself may be hazardous and increases the morbidity, with no practical benefit for the patient. Controversy exists regarding the total removal of complicated and risky lesions, but a subtotal excision should be considered in these cases due to the low recurrence reported even after subtotal excision.[17,25] As stated earlier, major complications can occur when leaving these tumors follow their natural history. We found that a persistent cyst debulking was a both safe and efficacious way for this tumor removal, and we now think that these lesions should be excised, even when patients are asymptomatic. Since all the cases reported are young people, we believe that a surgical option is preferable in most cases.

Our patient presented clinical improvement with no residual lesion detectable on MRI. With improvement in microneurosurgical techniques, many authors have reported total resection of intracranial dermoids, but there is some concern that an aggressive surgical approach is associated with a high mortality rate.[19,25] We believe that an aggressive tumor capsule removal is inappropriate when the lesion is adherent to neurovascular structures given the high risk of morbidity or mortality.[3, 17, 24] Also, the recurrence rate after subtotal removal seems to be low even if no further adjuvant treatment is associated.[11]

Go to:

\section{CONCLUSION}

Dermoid cysts of the cavernous sinus are tumors of children and young adults. A proper radiological evaluation must be made for an adequate preoperative plan. Total removal is the goal, but should not be attempted when these lesions are tightly adherent to basal neurovascular structures. Unlike many other cavernous sinus tumors, there is a favorable outcome regarding the extent of tumor resection and cranial nerve preservation for the interdural cavernous sinus dermoids. We believe that in these tumors, even if asymptomatic, surgery should be considered in an early stage due to the risk of compressing symptoms that may lead to irreversible neurological deficits, or rupture resulting in chemical meningitis.

Go to:

\section{ACKNOWLEDGMENT}

We thank Sérgio Lameiras for assistance in preparing the manuscript.

Go to:

Footnotes

Available FREE in open access from: http://www.surgicalneurologyint.com/text.asp?2012/3/1/10/92180

Go to:

\section{REFERENCES}

1. Abdelouafi A, Ousehal A, Gharbi A, Ait Benali S, El Kamar A, Kadiri R. Cavernous sinus dermoid cyst with unusual parapharyngeal development. J Neuroradiol. 2000;27:140-3. [PubMed: 10970966]

2. Alvord EC., Jr Growth rates of epidermoid tumors. Ann Neurol. 1977;2:367-70. [PubMed: 617575]

3. Akdemir G, Daglioglu E, Ergungor MF. Dermoid lesion of the cavernous sinus: Case report and review of the literature.

Neurosurg Ver. 2004;27:294-8.

4. Arseni C, Danaila L, Constantinescu AI, Carp N, Decu P. Cerebral dermoid tumors. Neurochirurgia. 1976;19:104-14.

[PubMed: 934416]

5. Chen YF, Liu HM, Tu YK. Dermoid cyst as a dumbbell-shaped tumour of the cavernous sinus. Pediatr Radiol. 2003;33:72.

[PubMed: 12599307]

6. Cohen JE, Abdallah JA, Garrote M. Massive rupture of suprasellar dermoid cyst into ventricles. J Neurosurg. 1997;87:963.

[PubMed: 9384413]

7. Dange N, Mahore A, Goel A. Ruptured giant dermoid cyst of the cavernous sinus. J Clin Neurosci. 2010;17:1056-8.

[PubMed: 20483617]

8. DeMonte F, Al-Mefty O. Ruptured dermoid tumor of the cavernous sinus associated with the syndrome of fat embolism: Case report. J Neurosurg. 1992;77:312-5. [PubMed: 1625022]

9. Dóczi TP, Sindou M. Vol. 2. Germany: Springer-Verlag/Wien; 2009. Epidermoid/Dermoid cysts. Practical handbook of neurosurgery: from leading neurosurgeons; pp. 301-17.

10. El-Kalliny M, Van Loveren H, Keller JT, Tew JM., Jr Tumors of the lateral wall of the cavernous sinus. J Neurosurg.

1992;77:508-14. [PubMed: 1527607]

11. Fournier D, Mercier P, Menei P, Pouplard F, Rizk T, Guy G. Recurrent intrinsic brainstem epidermoid cyst. Childs Nerv Syst. 1992;8:471-4. [PubMed: 1288859] 
12. Guidetti B, Gagliardi FM. Epidermoid and dermoid cysts - Clinical evaluation and late surgical results. J Neurosurg. 1977;47:12-8. [PubMed: 864501]

13. Classification of Headache Disorders, Cephalalgia - an International Journal of Headache. 2nd ed. Suppl 1. Vol. 24. Oxford: Blackwell Publishing; 2004. Headache Classification Subcommittee of the International Headache Society.

14. Hirsh WL, Hrynshko FG, Sekhar LN, Brunberg J, Kanal E, Latchaw RE, et al. Comparison of MR imaging, CT and angiography in the evaluation of the enlarged cavernous sinus. AJR Am J Roentgenol. 1989;151:1015-23.

15. Jamjoorn B, Cummins BH. The diagnosis of ruptured intracranial dermoid cysts. Br J Neurosurg. 1989;3:609-12. [PubMed: 2818854]

16. Liu JK, Gottfried ON, Salzman KL, Schmidt RH, Couldwell WT. Ruptured Intracranial Dermoid Cysts: Clinical, Radiographic, and Surgical Features. Neurosurgery. 2008;62:377-84. [PubMed: 18382315]

17. Lunardi P, Missouri P. Supratentorial dermoid cysts. J Neurosurg. 1991;75:262-6. [PubMed: 2072164]

18. Miller JP, Cohen AR, Schmidek HH, Roberts DW. 5th ed. Vol. 1. USA: Saunders Elsevier; 2006. Posterior fossa tumors: Surgical management of tumors of the fourth ventricle. Operative Neurosurgical Techniques; pp. 905-6.

19. Nakagawa K, Ohno K, Nojiri T, Hirakawa K. Interdural dermoid cyst of the cavernous sinus presenting with oculomotor palsy: Case report. No Shinkei Geka. 1997;25:847-51. [PubMed: 9300456]

20. North KN, Anthony JH, Johnston IH. Dermoid of cavernous sinus resulting in isolated oculomotor nerve palsy. Pediatr Neurol. 1993:9:221-3. [PubMed: 8352856]

21. Rubin G, Scienza R, Pasqualin A, Rosta L, Da Pian R. Craniocerebral epidermoids and dermoids. Acta Neurochir (Wien) 199;97:1-16. [PubMed: 2718791]

22. Tun K, Celikmez RC, Okutan O, Gurcan O, Beskonakli E. Dermoid tumour of the lateral wall of the cavernous sinus. J Clin Neurosci. 2008:15:820-3. [PubMed: 18462942]

23. Walker ML, Petronio J, Rengachary SS, Ellenbogen RG. Posterior fosa tumors: Dermoid tumors. Principles of Neurosurgery. 2nd ed. China: Mosby- Elsevier; 2005. pp. 548-9.

24. Yamakawa K, Shitara N, Genka S, Manaka S, Takakura K. Clinical course and surgical prognosis of 33 cases of intracranial epidermoid tumors. Neurosurgery. 1989;24:568-73. [PubMed: 2710302]

25. Yasargil MG, Abernathey CD, Sarioglu AC. Microneurosurgical treatment of intracranial dermoid and epidermoid tumors. Neurosurgery. 1989;24:561-7. [PubMed: 2710301]

Go to:

\section{Figures and Tables}

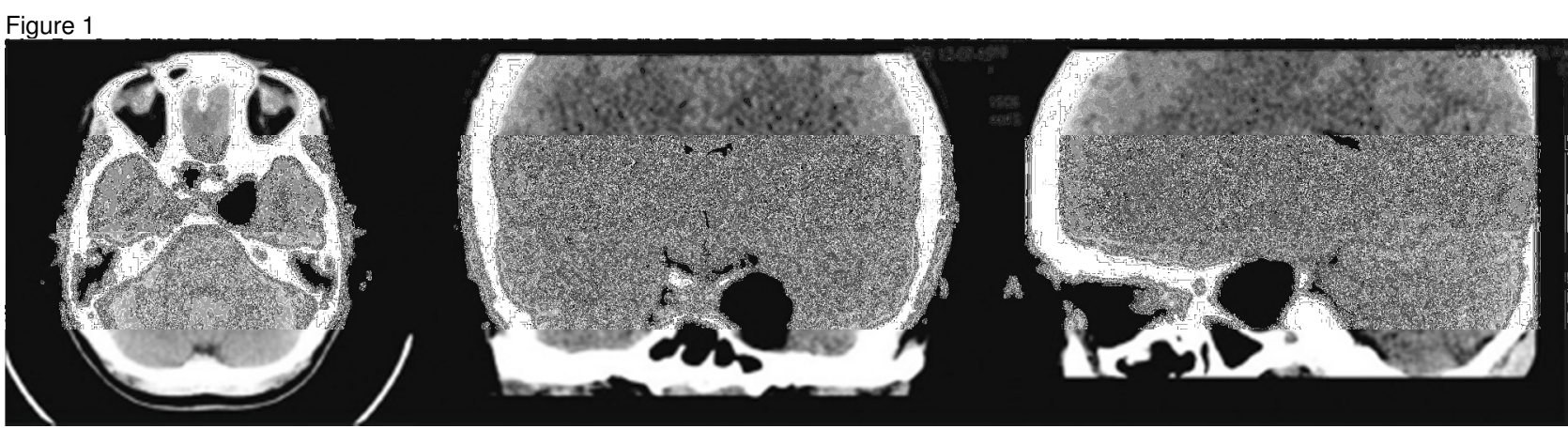

Axial, coronal, and sagittal CT imaging showing a strong hypodense left parasellar region lesion (fat density) with no contrast enhancement or vasogenic edema

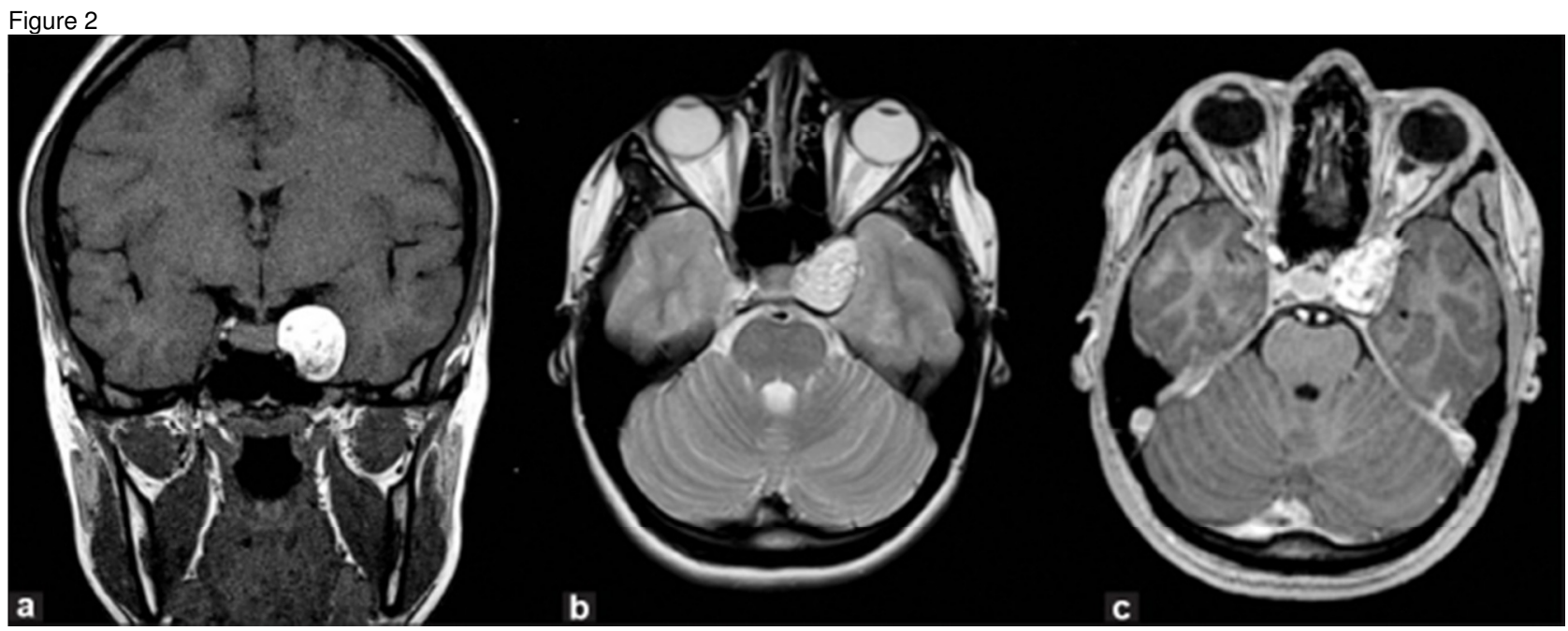

(a) Preoperative coronal T1-weighted MRI showing smooth contours and oval shape of the lesion and medial displacement of the intracavernous portion of the internal carotid artery without enhancement or narrowing. (b) Preoperative axial T2-weighted MRI showing a hyperintense lesion close to the left internal carotid artery with heterogeneous signal characteristics. (c)

Preoperative axial T1-weighted MRI showing the same lesion with heterogeneous gadolinium enhancement 


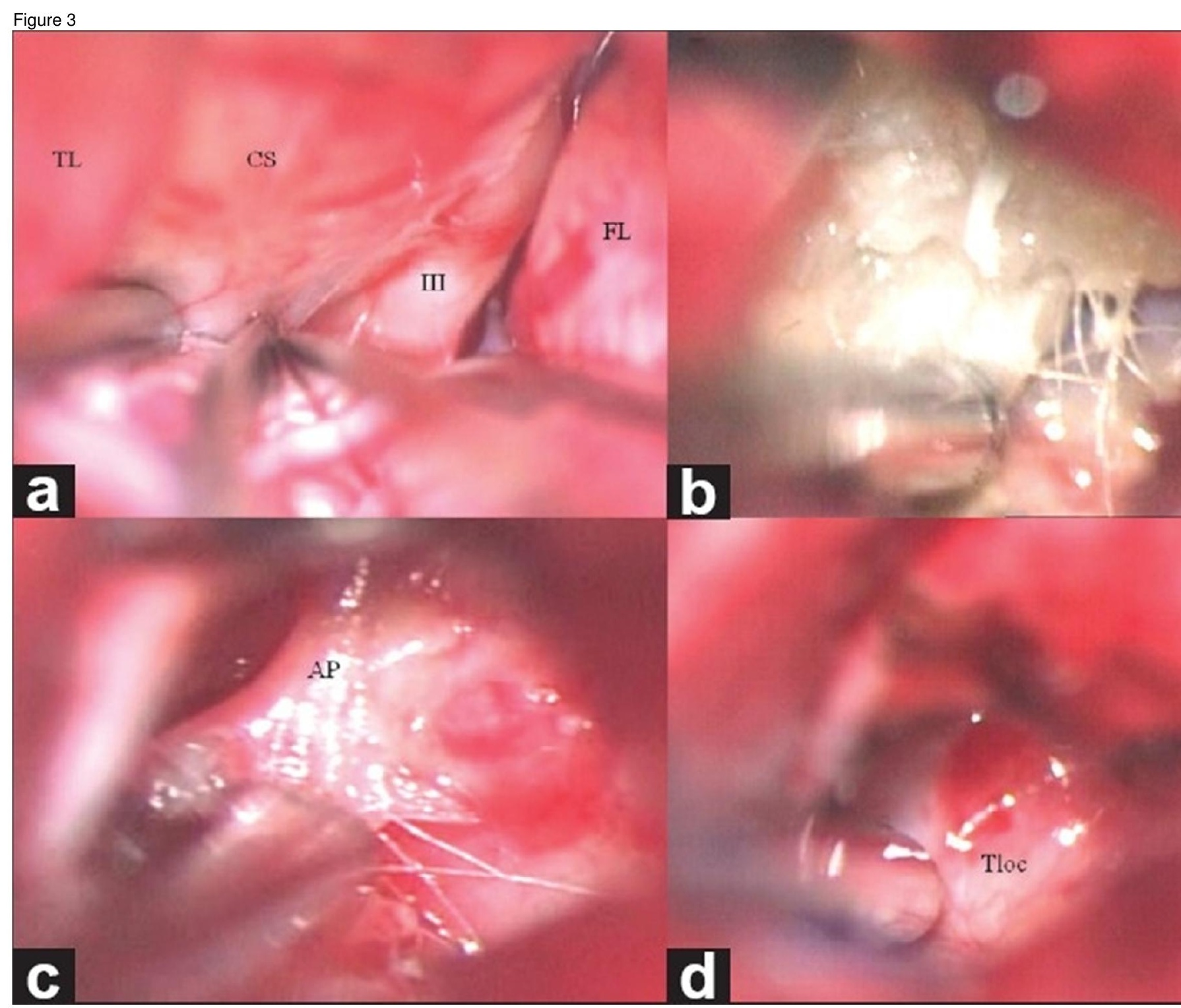

(a) Aspects of Sylvian approach with temporal lobe (TL) on the left and frontal lobe (FL) on the right, III nerve (III), and the lateral wall of the cavernous sinus (CS); (b) intracapsular hair fibers of the cyst; (c) interdural location and a point of attachment (AP) to the inner membranous layer of the lateral wall of the CS; (d) final view of the tumoral loca (Tloc)

Figure 4 


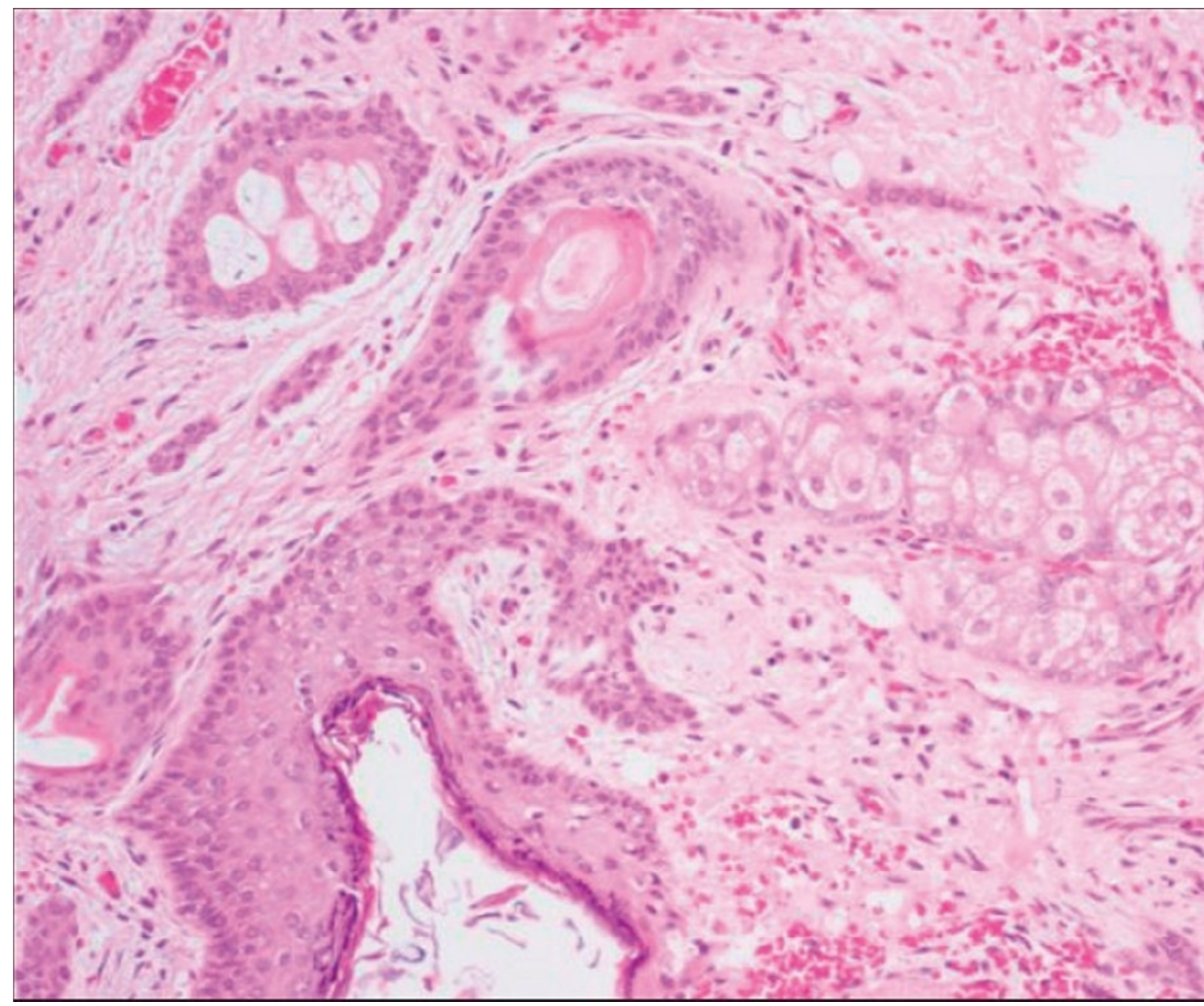

Histopathologic examination showed stratified squamous epithelium and abundant sebaceous glands, characteristic features of dermoid tumors $(\mathrm{H}$ and $\mathrm{E}, \times 40)$

Figure 5 


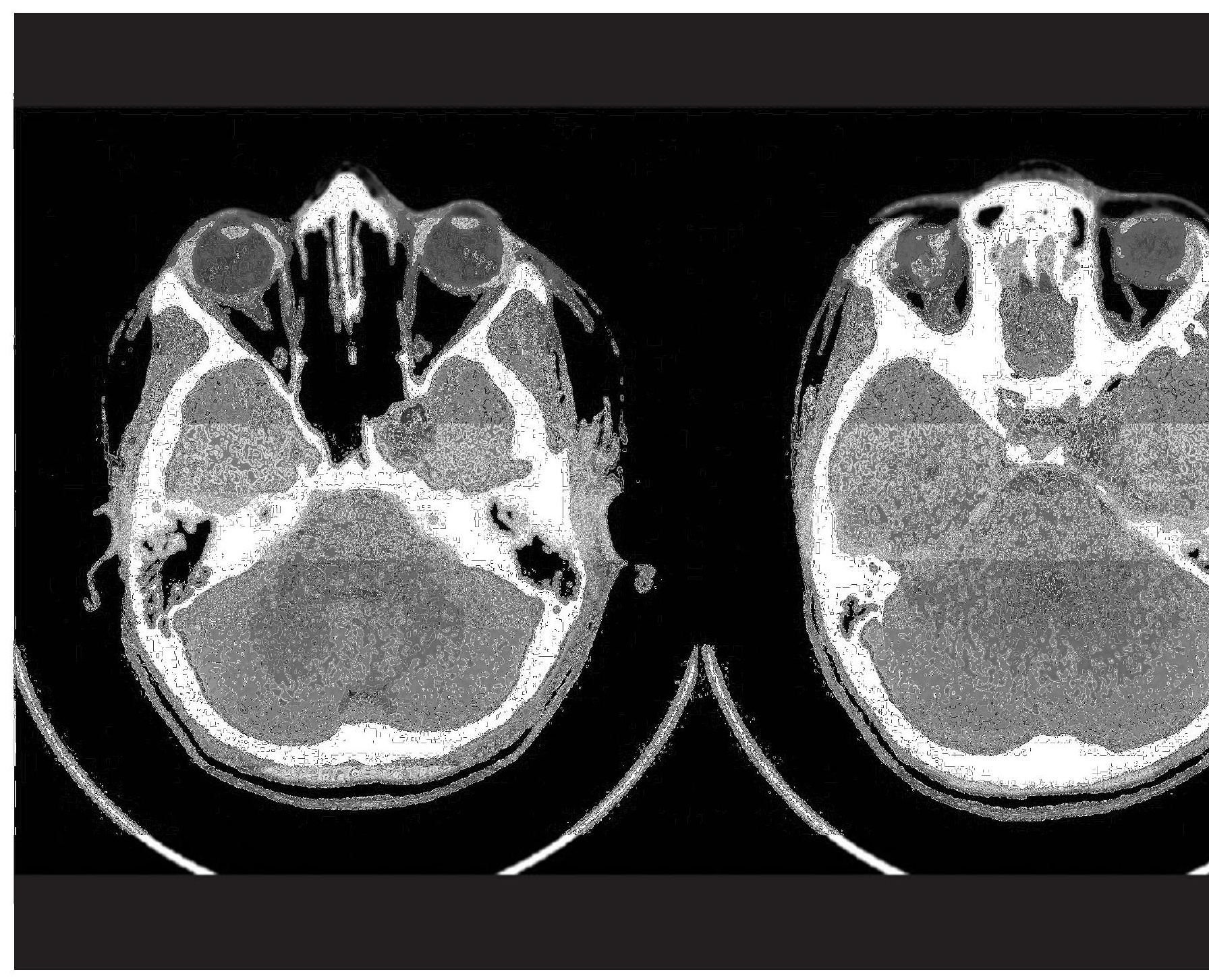

Immediate post-op CT scan showing complete tumor removal

Figure 6 


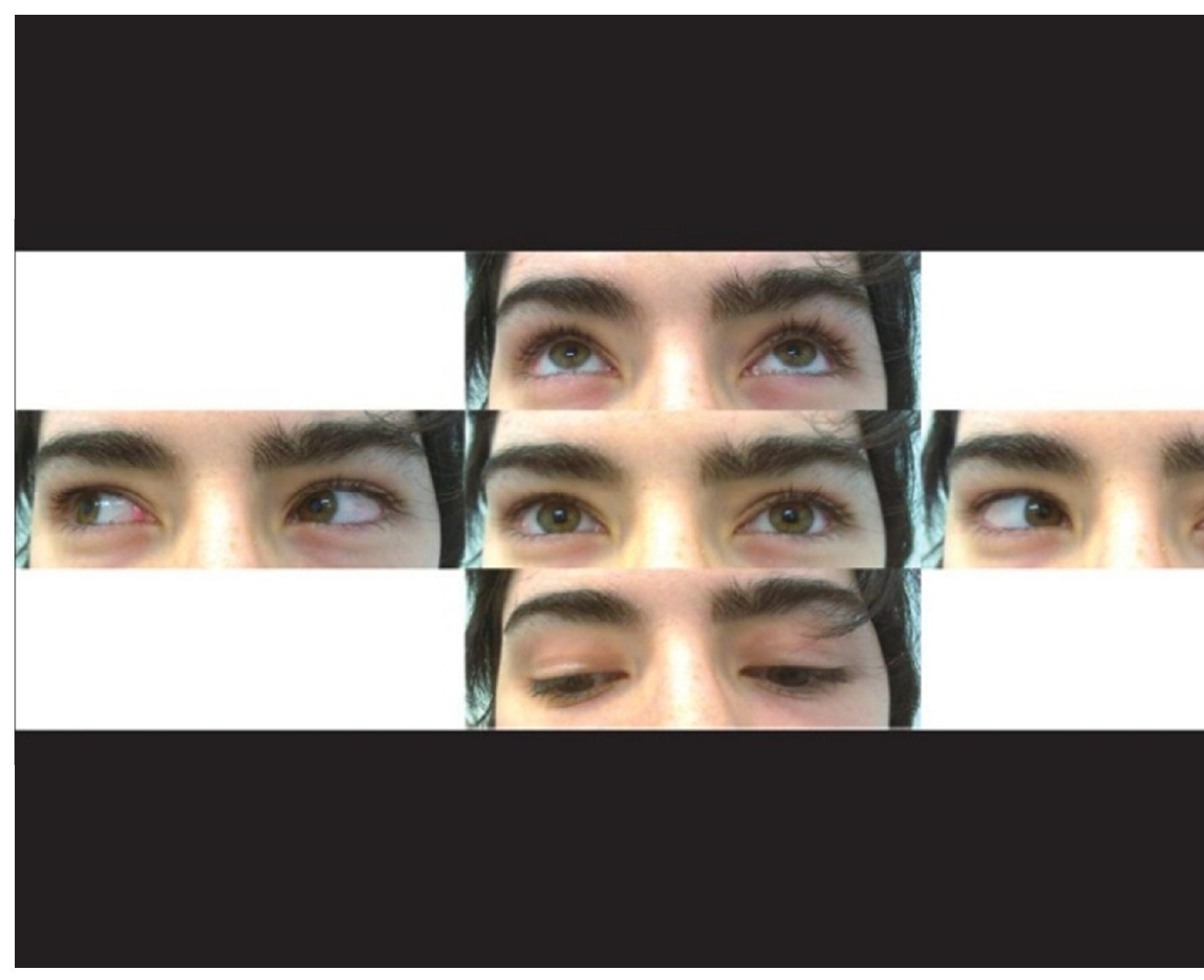

No ocular nerve palsies were seen post-op

Figure 7 


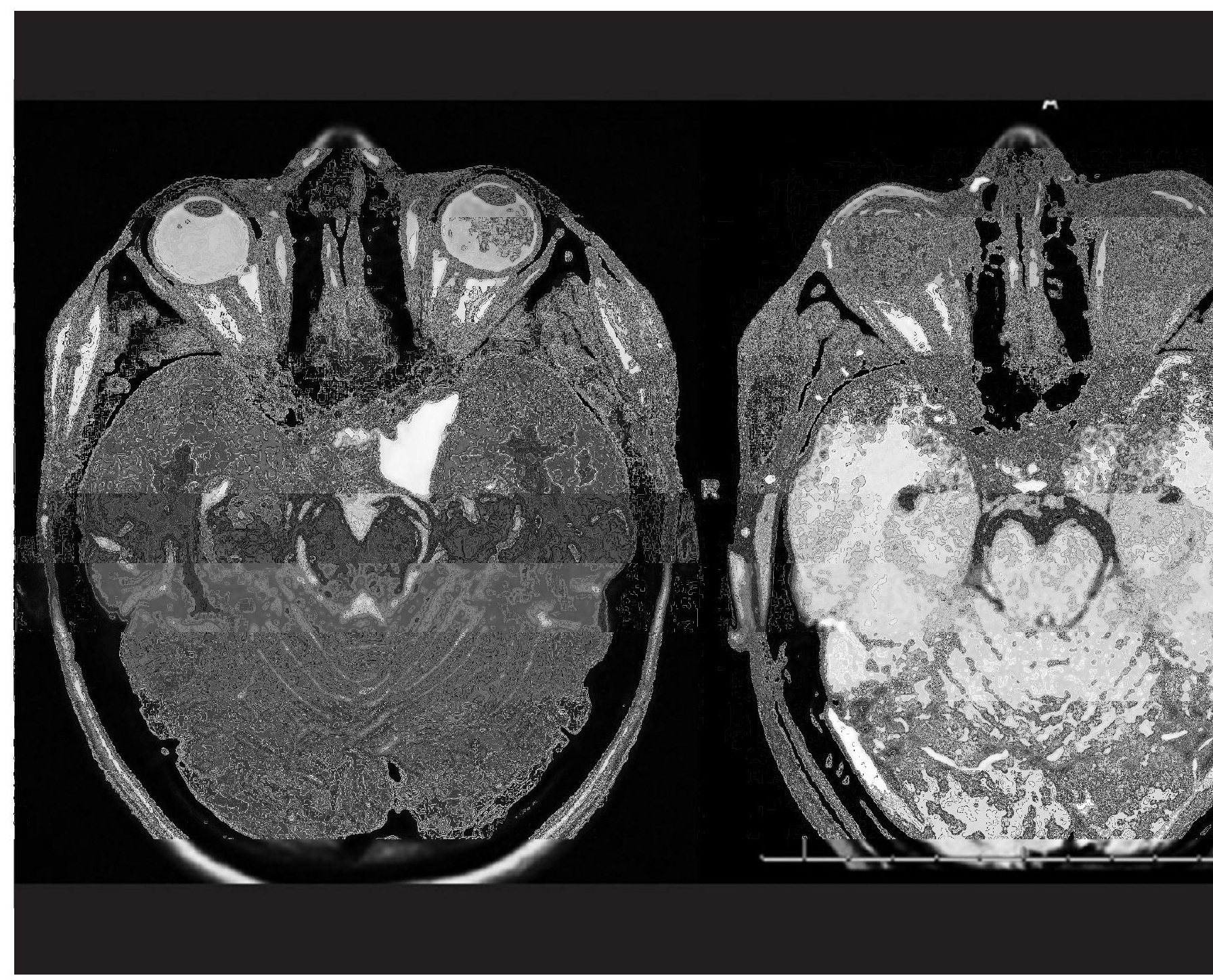

2-month post-op MRI with no residual lesion

Table 1 


\begin{tabular}{|c|c|c|c|c|c|c|c|}
\hline $\begin{array}{l}\text { Number } \\
\text { of report }\end{array}$ & Reference & $\begin{array}{l}\text { Age } \\
\text { (years)/ } \\
\text { Sex }\end{array}$ & Localization & Clinical aspects & $\begin{array}{l}\text { Operative } \\
\text { approach }\end{array}$ & Result & Outcome \\
\hline 1 & Lunardi, $1991^{[17]}$ & $\begin{array}{l}\text { NA, } 3 \\
\text { cases }\end{array}$ & $\begin{array}{l}\text { Point of attachment } \\
\text { to the cavernous } \\
\text { sinus }\end{array}$ & NA & NA & $\begin{array}{l}\text { Incomplete } \\
\text { removal }\end{array}$ & NA \\
\hline 2 & DeMonte, $1992^{[1]}$ & $27 / F$ & Intracavernous & $\begin{array}{l}\text { Headache, fat } \\
\text { embolism }\end{array}$ & $\begin{array}{l}\text { Cranio-orbito- } \\
\text { zygomatic } \\
\text { craniotomy }\end{array}$ & Total removal & $\begin{array}{l}\text { Neurologioally } \\
\text { normal, adult } \\
\text { respiratory distress } \\
\text { syndrome }\end{array}$ \\
\hline 3 & North, $1993^{201}$ & $4 / M$ & $\begin{array}{l}\text { Lateral wall of the } \\
\text { oavernous sinus, } \\
\text { between the leaves } \\
\text { of dura }\end{array}$ & $\begin{array}{l}\text { Isolated oculomotor } \\
\text { nerve palsy }\end{array}$ & NA & Total removal & Total reoovery \\
\hline 4 & $\begin{array}{l}\text { Nakagawa, } \\
1997^{[19]}\end{array}$ & $19 / F$ & $\begin{array}{l}\text { Right cavernous } \\
\text { sinus, interdural, } \\
\text { lateral wall attached }\end{array}$ & $\begin{array}{l}\text { Headache, diplopia, } \\
\text { disturbanoe of ocular } \\
\text { movements, slight } \\
\text { anisocoria }\end{array}$ & $\begin{array}{l}\text { Fronto-temporal } \\
\text { oraniotomy }\end{array}$ & Total removal & $\begin{array}{l}\text { Improvement of } \\
\text { diplopia }\end{array}$ \\
\hline 5 & $\begin{array}{l}\text { Abdelouafi, } \\
2000^{(1)}\end{array}$ & $12 / F$ & $\begin{array}{l}\text { Left cavernous sinus } \\
\text { and extension into } \\
\text { parapharyngium } \\
\text { areas }\end{array}$ & $\begin{array}{l}\text { Progressive } \\
\text { intraoranial } \\
\text { hypertension }\end{array}$ & NA & NA & Tumor recurrence \\
\hline 6 & Chen, $2003^{[5]}$ & $10 / M$ & $\begin{array}{l}\text { Left cavernous sinus } \\
\text { and interpedunoular } \\
\text { oistern }\end{array}$ & $\begin{array}{l}\text { Isolated left } \\
\text { ooulomotor palsy }\end{array}$ & NA & NA & NA \\
\hline 7 & Akdemir, 2004 & $18 / M$ & $\begin{array}{l}\text { Left wall of the } \\
\text { cavernous sinus, } \\
\text { interdural }\end{array}$ & $\begin{array}{l}\text { Headache, diplopia, } \\
\text { blurred vision, } \\
\text { ophthalmoplegia }\end{array}$ & $\begin{array}{l}\text { Fronto-orbito- } \\
\text { zygomatic } \\
\text { oraniotomy }\end{array}$ & Total removal & $\begin{array}{l}\text { Improvement in } \\
\text { diplopia and ptosis, } \\
\text { but no change in } \\
\text { ophthalmoplegia }\end{array}$ \\
\hline 8 & Tun, 2008 & $41 / F$ & $\begin{array}{l}\text { Lateral wall of the } \\
\text { cavernous sinus }\end{array}$ & $\begin{array}{l}\text { Headache, blurred } \\
\text { vision, diplopia, third } \\
\text { cranial nerve palsy }\end{array}$ & $\begin{array}{l}\text { Zygomatic } \\
\text { osteotomy with } \\
\text { a fronto-temporal } \\
\text { approaoh }\end{array}$ & $\begin{array}{l}\text { Gross total } \\
\text { removal }\end{array}$ & $\begin{array}{l}\text { Marked } \\
\text { improvement in } \\
\text { diplopia and ptosis }\end{array}$ \\
\hline 9 & Dange, $2010^{717}$ & $27 / M$ & $\begin{array}{l}\text { Cavemous sinus. } \\
\text { extending into the } \\
\text { posterior fossa }\end{array}$ & $\begin{array}{l}\text { Headache; seizures: } \\
\text { meningitis; diplopia; } \\
\text { fifth, sixth, and seven } \\
\text { nerve palsies }\end{array}$ & $\begin{array}{l}\text { Sub-temporal } \\
\text { approach }\end{array}$ & $\begin{array}{l}\text { Near-total } \\
\text { excision }\end{array}$ & $\begin{array}{l}\text { Improvement in } \\
\text { motor weakness } \\
\text { of the fifth and } \\
\text { seventh nerves and } \\
\text { relief from diplopia }\end{array}$ \\
\hline 10 & Present report & $21 / F$ & $\begin{array}{l}\text { Left wall of the } \\
\text { cavernous sinus, } \\
\text { interdural }\end{array}$ & $\begin{array}{l}\text { Headache, blurred } \\
\text { vision }\end{array}$ & $\begin{array}{l}\text { Left fronto- } \\
\text { temporal } \\
\text { oraniotomy }\end{array}$ & $\begin{array}{l}\text { Gross total } \\
\text { removal }\end{array}$ & Total recovery \\
\hline
\end{tabular}

Review of the dermoid cysts associated with the cavernous sinus, listed in historical order 